\title{
HYDROGEOLOGICAL HAZARD IN THE UNESCO WORLD HERITAGE SITE OF CASTELSEPRIO (NORTHERN ITALY)
}

\author{
E. DE FINIS, P. GATTINONI \& L. SCESI \\ Politecnico di Milano, Italy.
}

\begin{abstract}
This article describes the research activity carried out in the archaeological site of Castelseprio (northern Italy), dealing with the evaluation of the geomorphologic hazard and risk with regard to landslides and erosion processes for the historical site. A field analysis was conducted to reconstruct the geological and hydrogeological setting of the site, as well as its geomorphological characteristics. The aim was to identify the failure modes and their causative factors, which are mainly lithological, morphological and hydrogeological conditions. Collected data were stored in databases, and a GIS-based landslide susceptibility map was created from an inventory of landslide phenomena and other geological and geomorphological parameters that may directly influence landslides. Afterwards, the hydrogeological hazard was investigated, applying geological engineering methods in order to indicate the main causes of instability and the related remedial measures. Finally, the future development of the United Nations Educational, Scientific and Cultural Organization (UNESCO) site is discussed in order to guarantee its unity. With this aim, different hypothesis of pathways connecting the historical monuments are evaluated to find out the best solution.

Keywords: cultural heritage, erosion, GIS, Italy, landslide.
\end{abstract}

\section{INTRODUCTION}

The impact of natural hazards on cultural heritage represents an important theme, involving a multidisciplinary approach. The United Nations Educational, Scientific and Cultural Organization (UNESCO) encourages the identification, protection and preservation of cultural and natural heritage all around the world. A significant number of these sites are not in equilibrium with the environment [1]; many of them are continuously affected by several factors (both natural and human). Moreover, the concept of value during exposure and damage analysis cannot be merely applied to cultural heritage due to their singularity, peculiarity and unrepeatability.

A National Research Council study on Italian monuments included in the UNESCO World Heritage list has revealed that many of them (about 70\%) are affected by geological, geomorphological and engineering geological problems [2] and that the major geological problems concern floods and landslides. In the last decades, many studies were conducted to characterize landslide hazard for the safeguard of Italian historical sites. Most of these studies concern slope instability connected to rock blocks kinematics [3-5], which in Central Italy often affect hilltop historical town. All these studies involved traditional and innovative survey methods for the rock mass characterization (i.e., laser scanning) and lead to the definition of proper monitoring systems, which generally involve remote sensing techniques [6-8]. On the 
other hand, few studies were carried out in order to assess and mitigate landslide hazard in alluvial area [9].

This article deals with the archaeological site of Castelseprio/Torba, which from 2011 is part of the UNESCO network named 'Italia Langobardorum. Centri di potere e di culto (568-774 d.C.)'. The site has an outstanding value for Lombardy (Fig. 1(a)) both for its archaeological and monumental testimonials and for the environmental context. In spite of that, the use of the site is complex because of geological issues, which affect the site unity and, in the long period, may prejudice the safety of a part of the site. Actually, the site is by the time affected by frequent slope instabilities along the entire hillslope. Therefore, in the present article an assessment of the geomorphologic hazard was carried out, with regard to landslides and erosion processes. First, a field analysis was conducted to reconstruct the geological and hydrogeological setting of the site, its geomorphological characteristics and the mitigation devices already present in order to identify the failure modes and their causative factors. Collected data were stored in proper databases. Afterwards a GIS-based landslide susceptibility map was created from an inventory of landslide phenomena and other geological and geomorphological parameters that may directly influence landslides. Moreover, the hydrogeological hazard was investigated, applying geological engineering methods in order to indicate the main causes of instability and the possible remedial measures. Finally, the future development of the UNESCO site is discussed in order to guarantee its unity. With this aim, different hypothesis of pathways connecting the historical monuments are evaluated to find out the best solution.

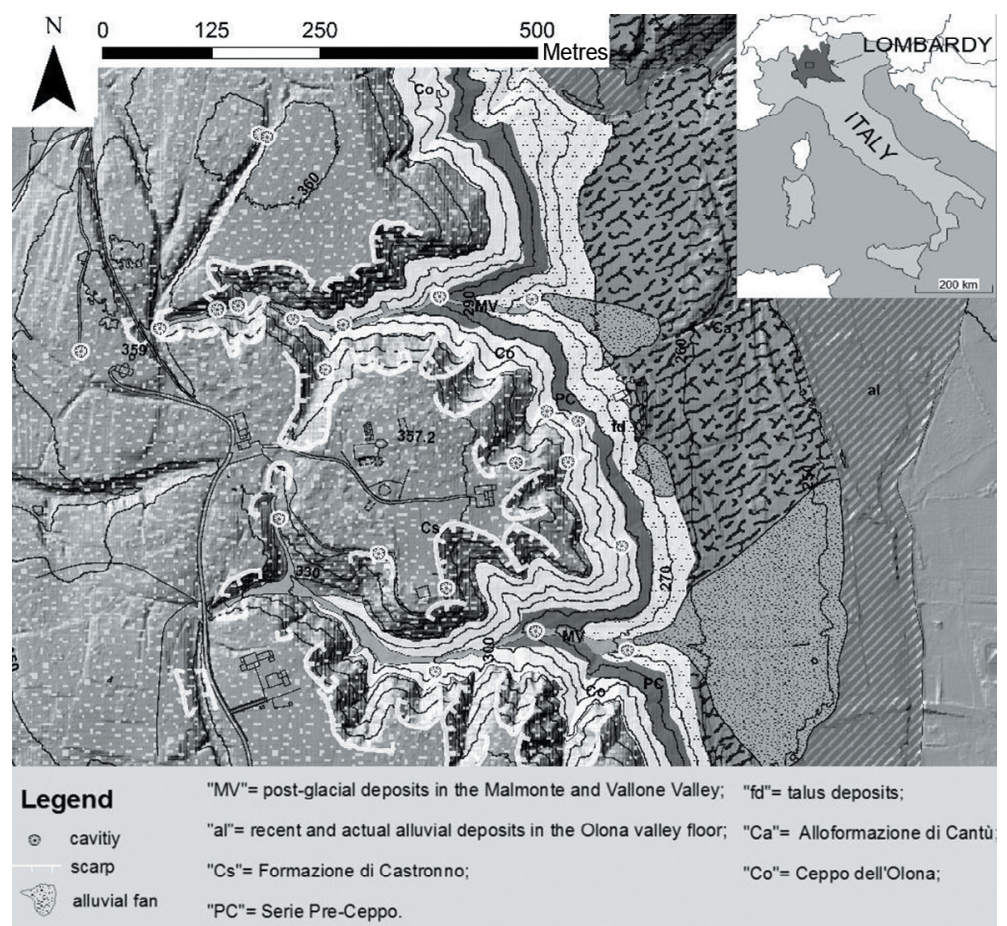

Figure 1: Geological and geomorphological map of the study area. 


\section{SITE DESCRIPTION}

This article concerns the UNESCO World Heritage site of Castelseprio/Torba (northern Italy, Fig. 1), which extends to an area of about $2 \mathrm{~km}^{2}$ along the hilly moraine zone of the Olona Valley (western Lombardy), and it includes the Archaelogical Park of Casteseprio, the Santa Maria Foris Portas Church and the Torba Monastery. More in detail, the study zone is constituted by a hilltop area at an altitude of $360 \mathrm{~m}$ a.s.l., delimitated by a morphological scarp having high slope towards the East, where it downgrades towards the middle Olona Valley (altitude of $260 \mathrm{~m}$ a.s.1.).

From a geological point of view, the area is characterized by the presence of glacial, fluvioglacial and alluvial deposits [10,11], covering an arenaceous-conglomeratic bedrock (Gonfolite, Oligo-Miocene). More in detail, in the flood-plain area, where the Torba Monastery is present, the Alloformazione di Cantù (glacial deposits, mainly gravels with sands) is outcropping and then degrading towards the alluvial deposits of the Olona River (Fig. 1(b)).

The Formazione di Castronno (fluvio-glacial deposits, mainly gravels and sands with clay, locally very weathered) makes up the hilltop zone, where the Archaeological Park is located, and it is locally covered by loess deposit. The Formazione di Castronno has a thickness of about 25-30 m, and it can be divided into two subunits: a surface unit having a low degree of weathering and a deeper one having a very high weathering degree, where the deposit turns up to be very clayed.

Two main streams deeply incise this deposit on both the southern and northern borders of the hill. Consequently, in the lateral valleys the Ceppo (alluvial conglomerate, mainly pubbles, gravels and sands) outcrops, with an average thickness of about $20 \mathrm{~m}$.

Below the Ceppo, pre-Ceppo (fluvial deposits, mainly gravels and sands, locally cemented and weathered) is present with a thickness over $50 \mathrm{~m}$, and more in depth (at an altitude of 240-230 m a.s.1.) the Argille di Castel di Sotto (marine deposits, mainly clays with sand and gravel layers) constitutes the impermeable bedrock of the main aquifer of the Olona Valley.

The water table of this main aquifer is located at the depth of 2-3 $\mathrm{m}$ in the floodplain area, whereas in the hilltop zone, the aquifer is at a depth of about $90 \mathrm{~m}$ from the land surface, and therefore it cannot affect landslide phenomena. On the contrary, slope stability can be affected by the groundwater flowing at higher altitude within the Ceppo, where the flow path is ruled by fractures and cavities widely present in this conglomerate (Fig. 2). Moreover, groundwater is also present in the surface layer of the Formazione di Castronno, because of the presence of layers having different hydraulic conductivity. Actually, the high weathering degree of the Formazione di Castronno at a depth of about 4-6 m from the land surface brings about a decrease in its hydraulic conductivity, therefore favouring standing water on the hilltop, as well as the existence of local suspended aquifers, whose flow path is often ruled by pipes.

\section{COLLECTED DATA}

\subsection{Geomorphological analysis}

Field surveys integrated with interpretation of aerial photographs permitted the drawing of a geomorphic map (Fig. 1(b)) containing the main hazard sources. The overall picture arising from the survey activity describes a situation of general and widespread instability. 

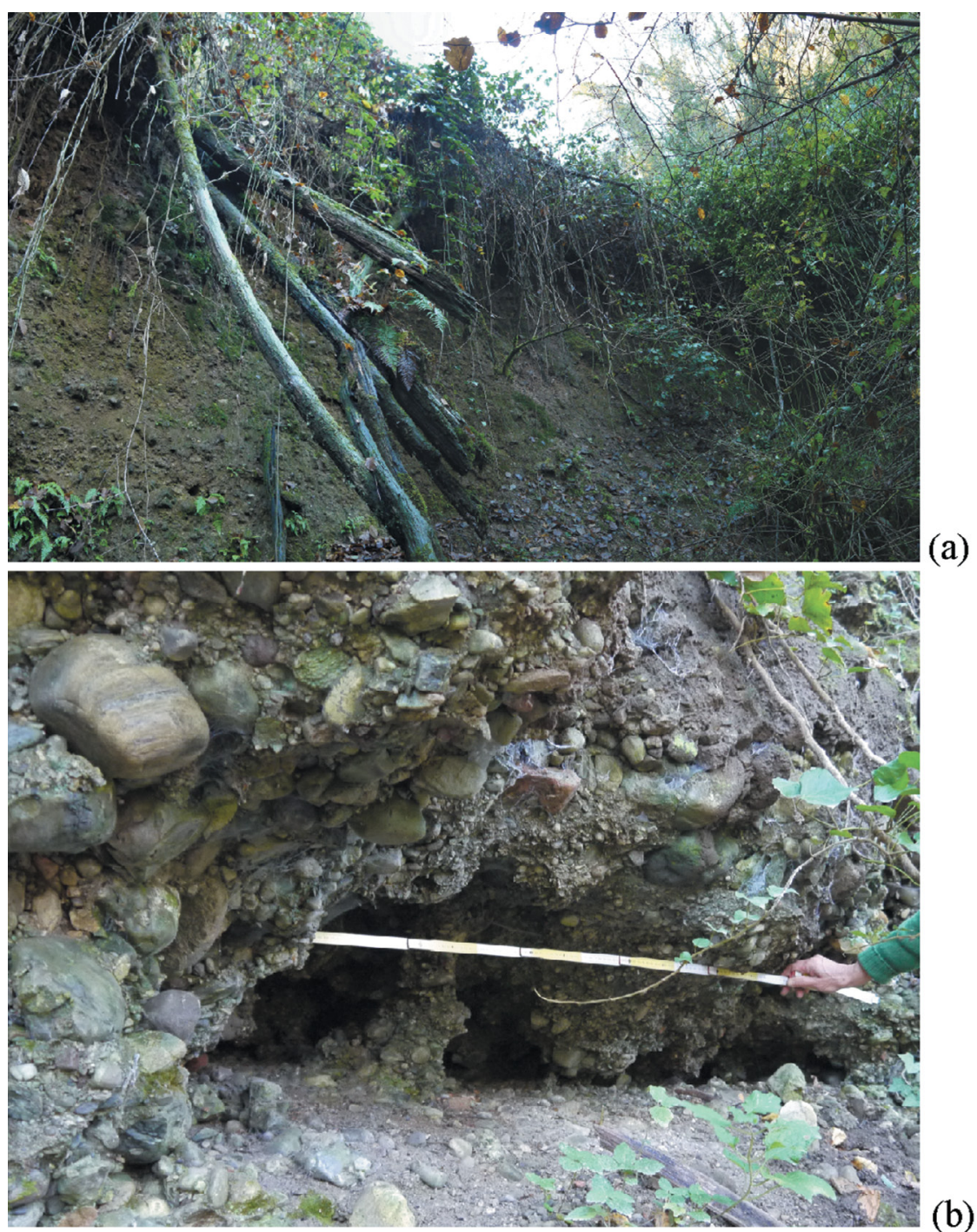

(a)

Figure 2: Example of (a) erosional phenomenon, and (b) cavity within the Ceppo formation.

More in detail, the in situ surveys showed a widespread instability within the two main catchment basins bordering the hilltop, with a number of landslide and erosion scarps along the stream banks, as well as flow obstructions due to both vegetation and landslides. Moreover, the watersheds of the two basins are often coincident with the scarps of several active landslides (Fig. 1(b)). Erosional phenomena and retraction of the edge (Fig. 2(a)) of the scarps are also widely present along the eastern slope (downgrading from the hilltop towards the floodplain area), which have already involved local settlements along the border of the Archaeological Park. Moreover, in this area rockfalls are also present within the Ceppo formation, especially where it outcrops on high slope. Actually, the geological weakness of the conglomerate (connected to its high weathering and fracturing degree [Fig. 2(b)]) can lead to the instability of rock blocks having a volume from 1 to $10 \mathrm{~m}^{3}$. 
Table 1: Geotechnical units identified in the study area.

\begin{tabular}{llllllc}
\hline Unit & Lithology & Depth $(\mathrm{m})$ & $\gamma\left(\mathrm{kN} / \mathrm{m}^{3}\right)$ & $c(\mathrm{kPa})$ & $\phi\left(^{\circ}\right)$ & $E(\mathrm{MPa})$ \\
\hline A & Loess & $0-1$ & & & & \\
B & Castronno & $1-6.5$ & $15-18$ & $35-45$ & 28 & $4-5$ \\
C & Weathered Castronno & $6.5-20$ & $18-20$ & $70-80$ & 32 & 10 \\
D & Ceppo & $20-45$ & & & & \\
E & Pre-Ceppo & Over 45 & & & & \\
\hline
\end{tabular}

\subsection{Geotechnical characterization}

The penetrometric tests carried out on the hilltop area showed for the Formazione di Castronno geotechnical characteristics from fair to poor, especially in the surface layer, whereas the relative density of the soil increases with depth. Based on the available data, in the study area, different geotechnical units can be identified (Table 1).

Units $\mathrm{A}$ and $\mathrm{E}$ do not contribute directly to instability phenomena, whereas technical parameters for Units B, C and D should be defined. As far as Units B and C are concerned, the penetrometric tests gave values of $N_{\text {spt }}$ lower than 10 in the first 6-7 m from the land surface (Unit B), whereas for depth higher than 7-8 m (Unit C), $N_{\text {spt }}$ reaches values ranging from 14 to 25 . Based on the actual empirical correlation for interpreting the results of penetrometric tests, the main geotechnical parameters can be assessed (Table 1).

Unfortunately, no direct data are available in order to characterize the geotechnical behaviour of Unit D. Nevertheless, some geophysical investigations carried out in a near area demonstrated the high heterogeneity of the conglomerate. Actually, geophysical investigation showed the presence of local detensioned zone, where the resistivity decreases from 1000 to 20-30 $\Omega \mathrm{m}$ and the seismic velocity does not exceed $500 \mathrm{~m} / \mathrm{s}$. These weak zones are located along the edge of the slope and involve the conglomerate for a depth up to $10 \mathrm{~m}$, bringing about a groundwater concentration and local instabilities, such as rockfalls.

\subsection{Conceptual model for slope evolution}

The hydrogeological setting of the study area favours the presence of suspended aquifers, which may strongly affect gravitational processes and slope evolution (Fig. 3(a)). More in detail, the low slope and hydraulic conductivity in Unit A can bring about water standing on the hilltop area. The rainfall inclines to infiltrate within the Unit B, along pipes, which generally have a diameter smaller than $10 \mathrm{~cm}$. The surface deposit, when saturated, lost its cohesion and triggered slope instability along the edge of the main scarp. These instabilities may be a serious potential hazard for the Archaeological Park, as the progressive retreat of the scarp may involve the walls of the ancient town.

For a preliminary assessment of the stability conditions within Units B and C, the critical heights were evaluated in not drained conditions. As Unit D is a competent layer, and knowing the range for the specific yield and the cohesion of Units B and C, a slope ranging from $40^{\circ}$ to $60^{\circ}$ was considered, and a critical height ranging from 10 to $16 \mathrm{~m}$ was pointed out. Moreover, a preliminary drained analysis was carried out using the stability charts [12], and the stability factor was assessed for different hydraulic conditions and scarp heights (Fig. 3(b)). Results showed that for high slope (more than $60^{\circ}$ ) the stability is guaranteed in 

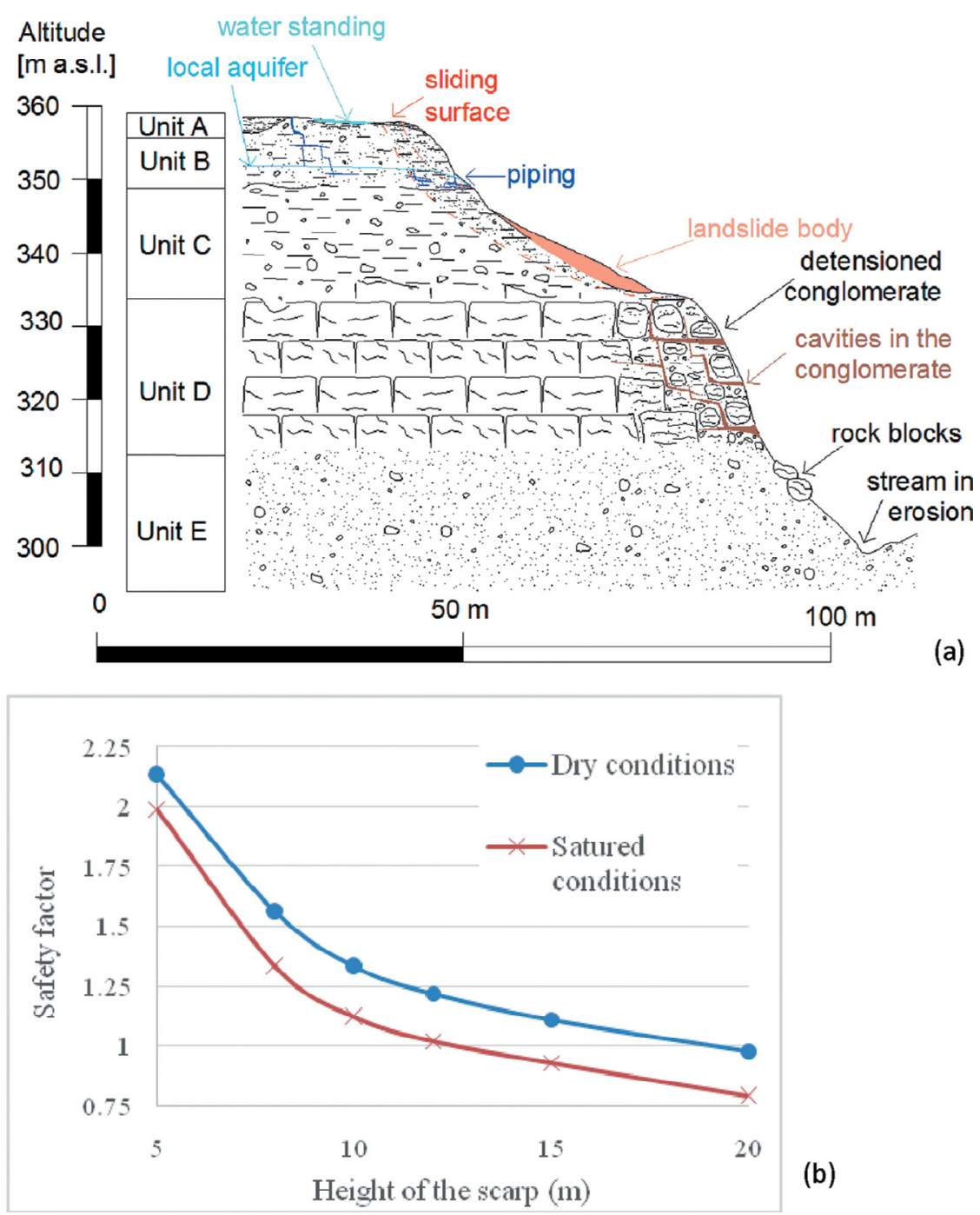

(b)

Figure 3: (a) Schematic representation of the conceptual model for slope evolution. (b) Safety factor for different heights of the scarp and hydraulic conditions ( slope $=60^{\circ}$ ).

dry conditions for scarp heights lower than 10-15 m. On the other hand, groundwater may trigger slope instability for scarp heights ranging from 8 to $13 \mathrm{~m}$.

\section{FUTURE CONSERVATION STRATEGIES}

\subsection{Landslides susceptibility assessment}

The strong geomorphological dynamic which characterizes the study area may cause serious loss of the cultural and archaeological heritage. Therefore, an assessment of the landslide susceptibility of the whole site was carried out. With this aim, an indirect statistical method 


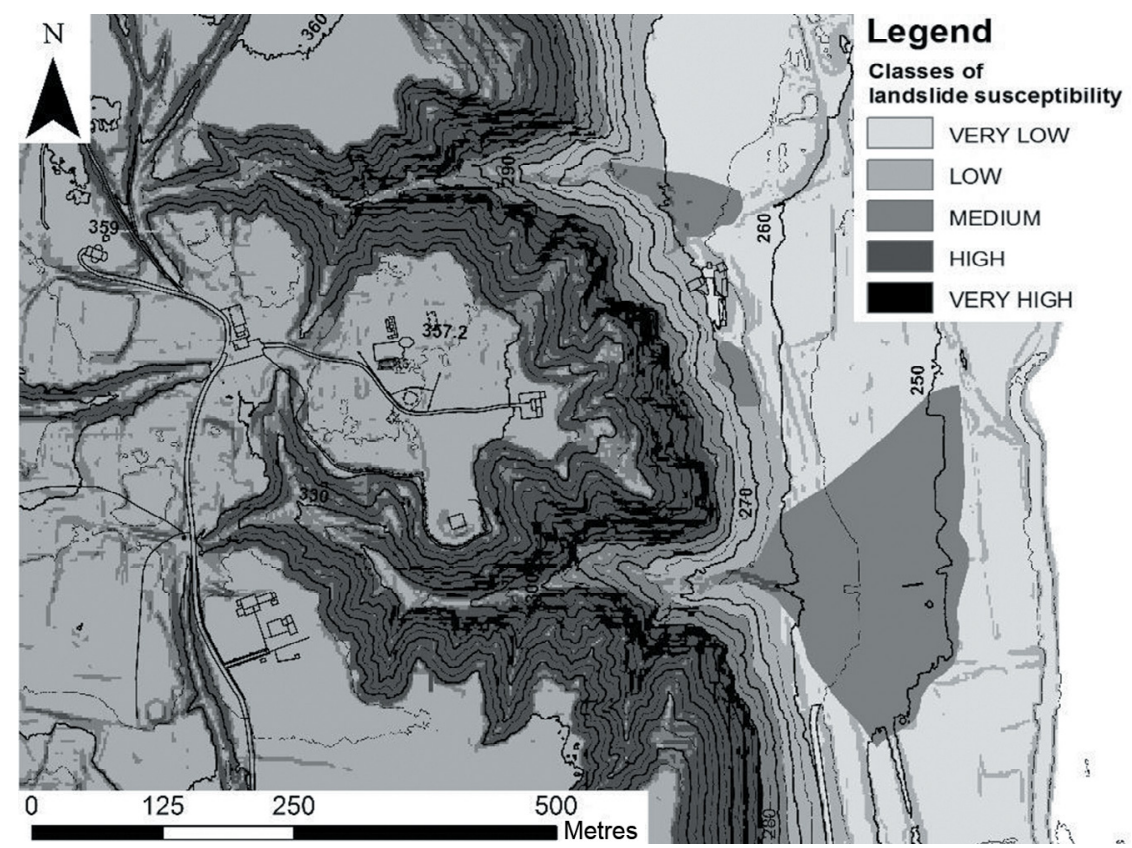

Figure 4: Landslide susceptibility map of the study area.

was used, considering the main factors affecting slope stability that are lithology and slope. The study area was divided with a mesh of $2 \times 2 \mathrm{~m}$. Afterwards, each factor was divided into classes and each class was weighted based on the landslide map.

In this way, the study area has been divided into zones having a different susceptibility to landslide, from very low to very high (Fig. 4). The map highlights that the slope mainly rules the slope dynamic: the susceptibility is generally high along the slope surrounding the hilltop area, and it is very high in the outcropping area of the conglomerate.

As a result, the Archaeological Park lies in a low susceptibility area, with the exception of its border zone, which is very close to the active scarps. On the other hand, in the area of the Torba Monastery, the susceptibility is from medium to high, because of the proximity of the rockfall area of the conglomerate, which outcrops a few meters above the monastery.

\subsection{Risk mitigation policy}

This article shows a very worrying picture in relation to the geomorphological dynamic of the area pertaining to the Archaeological Park. However, the lack of subsurface data useful to reach a complete characterization of geomaterials prevents a real quantification of the landslide hazard. Then, in order to complete the conceptual model previously described, a geological survey campaign would be necessary including

- penetrometric tests along the two main valleys, aimed at assessing the decay due to weathering and piping in the geotechnical parameters of Units B and C in the zones mostly affected by instability; and 
Table 2: Synthesis of the potential hazards affecting the different zones of the study area and the related mitigation measures.

\begin{tabular}{|c|c|c|}
\hline Location & Remedial measure & Objectives \\
\hline Hilltop & $\begin{array}{l}\text { Sheet drains and drainage } \\
\text { canals }\end{array}$ & $\begin{array}{l}\text { To avoid water standing and infiltration, which } \\
\text { may lead to settlements in the foundations of } \\
\text { the historical site }\end{array}$ \\
\hline \multirow[t]{3}{*}{$\begin{array}{l}\text { Slopes and } \\
\text { scarps }\end{array}$} & $\begin{array}{l}\text { Drainage trenches, timber } \\
\text { piles or retaining walls in } \\
\text { wood }\end{array}$ & $\begin{array}{l}\text { To reduce water seepage and soil } \\
\text { deformability }\end{array}$ \\
\hline & Benches and geosynthetics & To control surface erosion \\
\hline & $\begin{array}{l}\text { Rock netting and protection } \\
\text { barriers }\end{array}$ & To reduce rockfalls hazard and vulnerability \\
\hline River beds & Check dams & To reduce erosion and solid transport \\
\hline
\end{tabular}

- geophysical surveys both on the hilltop (i.e., georadar to detect detensioned zones, especially in the peripheral band of the site) and along the slopes at an altitude of about $330 \mathrm{~m}$ a.s.l. (i.e., electric and seismic investigations, aimed at characterizing the geomechanical behaviour of the conglomerate, are useful for evaluating the anchorage depth of possible rods).

These further investigations are also quite useful in order to design the mitigation devices (Table 2), which would include erosion and flood control works along the streams (i.e., check dams and bank protection), as well as stabilization measures on the slopes (i.e., slope reshaping, rods and supporting walls).

\subsection{Sustainability and site development}

The future development of the UNESCO World Heritage site presupposes the realization of a pathway connecting the Castrum, located on the hilltop zone, and the Torba Monastery, located in the floodplain area, in order to guarantee the unity of the site.

Actually, in spite of the nearness of the Castrum and the monastery (the distance is less than $300 \mathrm{~m}$ ), the unity of the site has always been a complex issue, because of the morphology (the difference in level is about $100 \mathrm{~m}$ ) and the widespread instability of the area. Nowadays, the only way forward from the Castrum to the monastery is a driveway having a length of more than $3 \mathrm{~km}$.

In historical time, a pathway existed (historical pathway in Fig. 5), which developed along the Vallone Valley on a distance of about $1 \mathrm{~km}$. Some tracks of this pathway still exist, but they are discontinuous because of the dense shrubbery and the widespread instability phenomena, which characterize the whole valley. The cleanliness and the safety of this pathway could be difficult in the long time and quite expensive, because of its length and the geological problems (rockfalls, sliding landslides, erosion, etc.) widely affecting the valley.

Based on the evidences achieved in the present article two other possible pathways could be safe to go through:

- The Castrum pathway, which goes up along the slope directly from the monastery to the Castrum, for a total length of about $300 \mathrm{~m}$. It develops entirely within the area of the 

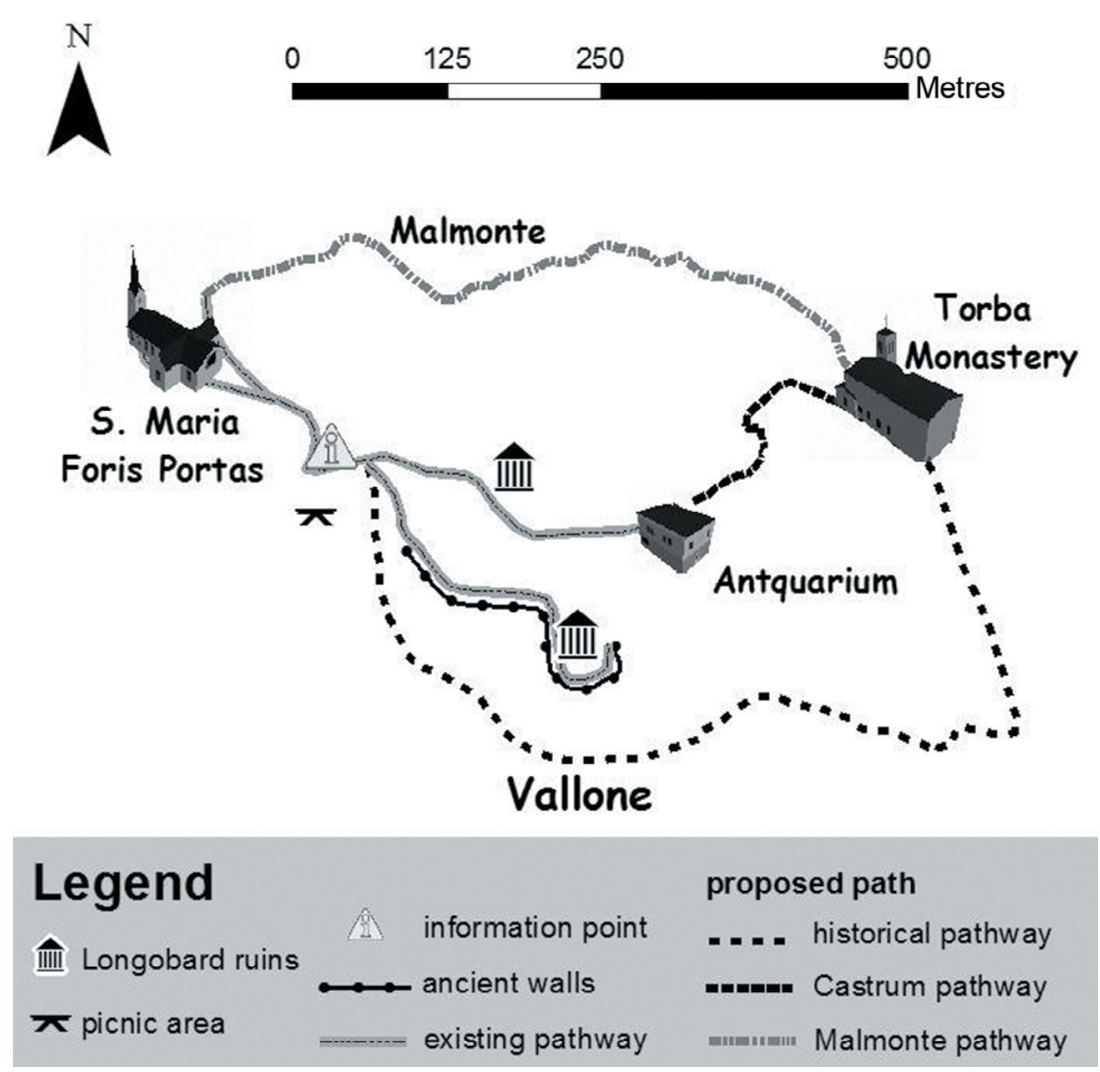

Figure 5: Map of the pathways that are able to connect the different historical monuments of the site.

historical site, even with high slope. Moreover, it crosses the zone interested by rockfalls in the conglomerate and then it deserves the realization of rods and netting barriers in order to reduce the risk.

- The Malmonte pathway, which develops along the valley for a total length of about $650 \mathrm{~m}$. Even if this track is shorter than the historical pathway, it deserves a number of stabilization measures (rods, nets, supporting wells, check dams, etc.) because of the widespread instability which characterizes the valley.

\section{CONCLUSIONS}

The case investigated is a good example of archaeological area threatened by hydrogeological hazard in its various forms: slope instability, and soil and fluvial erosion. In the present article, a detailed geomorphic characterization was carried out in order to determine the mechanisms of instability and the conceptual model of slope evolution, which is the starting point for the planning of remedial measures, both in terms of management policy and development strategies. 
According to the present article and filed missions, predominant and more frequent geomorphological processes in Castelseprio site are the following:

1. Erosion and water run-off in the small catchments below the site. These phenomena may cause soil slips and debris flows during heavy rainfall.

2. Rockfalls within conglomerates; the Torba Monastery and any pathways connecting it to the upper Casteseprio site are the most exposed to these phenomena.

3. Roto-translational slides along the cliffs, potentially involving the walls of the upper site of Castelseprio.

4. Local subsidence on the top of the hill connected to infiltration and piping phenomena.

Items 1 and 2 may mainly involve tourists in their evolution, whereas items 3 and 4 are mainly relevant for the conservation of cultural heritage. Consequently, future investigation will require the following:

- A better understanding of the role and combination of different predisposing factors, especially with reference to the mechanical characteristics of materials and the hydrogeological boundary conditions

- A better understanding of triggering factors, especially regarding rain infiltration and piping evolution [13]

- Specific stability analysis on the main landslides in order to define failure state in terms of intensity, potential evolution and impact

The collected data will be the basis for future activities to be completed with local authorities for a complete hazard and risk characterization of the archaeological site and for the development of an early warning system to allow a safe exploitation of the touristic activities and for historical site preservation.

\section{REFERENCES}

[1] Canuti, P., Margottini, C., Fanti, R. \& Bromhead, E.N., Cultural heritage and landslides: Research for risk prevention and conservation. Landslides - Disaster Risk Reduction, eds. K. Sassa \& P. Canuti, Springer: Berlin, pp. 401-433, 2009.

[2] Lollino, G. \& Audisio, C., UNESCO World Heritage sites in Italy affected by geological problems, specifically landslide and flood hazard. Landslides, 3, pp. 311-321, 2006.

[3] Margottini, C., Antidze, N., Corominas, J., Crosta, G.B., Frattini, P., Gigli, G., Giordan, D., Iwasaky, I., Lollino, G., Manconi, A., Marinos, P., Scavia, C., Sonnessa, A., Spizzichino, D. \& Vacheishvili, N., Landslide hazard monitoring and conservation strategy for the safeguard of Vardzia Byzantine monastery complex, Georgia. Landslides, 12, pp. 193-204, 2015.

[4] Fanti, R., Gigli, G., Lombardi, L., Tapete, D. \& Canuti, P., Terrestrial laser scanning for rockfall stability analysis in the cultural heritage site of Pitigliano (Italy). Landslides, 10, pp. 409-120, 2013.

[5] D’Amato Avanzi, G., Marchetti, D. \& Puccinelli, A., Cultural heritage and geological hazards: the case of the Calomini hermitage in Tuscany (Italy). Landslides, $\mathbf{3}$, pp. 331-340, 2006.

[6] Agapiou, A., Lysandrou, V., Alexakis, D.D., Thermistocleous, K., Cuca, B., Argyriou, A., Sarris, A. \& Hadjimitsis D.G., Cultural heritage management and monitoring using 
remote sensing data and GIS: The case study of Paphos area, Cyprus. Computers, Environment and Urban Systems, 54, pp. 230-239, 2015.

[7] Tapete, D., Fanti, R., Cecchi, R., Petrangeli, P. \& Casagli, N., Satellite radar interferometry for monitoring and early-stage warning of structural instability in archaeological sites. Journal of Geophysics and Engineering, 9, pp. S10-S25, 2012.

[8] Zhou, W., Chen, F. \& Gou, H., Differential radar interferometry for structural and ground deformation monitoring: a new tool for the conservation and sustainability of cultural heritage sites. Sustainability, 7, pp. 1712-1729, 2015.

[9] Lazzari, M., Geraldi, E., Lapenna, V. \& Loperte, A., Natural hazards vs human impact: an integrated methodological risk assessment on the Tursi historical site, Southern Italy. Landslides, 3, pp. 275-287, 2006.

[10] Zuccoli, L., Geologia dei Pianalti di Castelseprio e Tradate (Provincia di Varese). Italian Journal of Quaternary Sciences, 13, pp. 57-80, 2000.

[11] Bini, A., Stratigraphy, chronology and paleogeography of quaternary deposits of the area between the Ticino and Olona Rivers (Italy, Switzerland). Geologia Insubrica, pp. 21-46, 1997.

[12] Hoek, E. \& Bray, J.W., Rock Slope Engineering, Institute of Mining and Metallurgy, E\&FN Spon: Londra, 1981.

[13] Gattinoni, P. \& Francani, V., A tool for modeling slope instability triggered by piping. World Academy of Science, Engineering and Technology, 56, 2009. 